\title{
MED12 Gene Mutation
}

National Cancer Institute

\section{Source}

National Cancer Institute. MED12 Gene Mutation. NCI Thesaurus. Code C150689.

A change in the nucleotide sequence of the MED12 gene. 